\title{
Faculty Rank of Professional Librarians-Part II
}

Mr. Lundy is director of libraries, University of Nebraska. 'This is the second of two articles on this topic.

$\mathrm{T}$ HE identification of the library professional staff with the teaching and research staff, rather than with the clerical and administrative staff, has been firmly established not only at Louisiana State University and the University of Illinois, but also at Oklahoma A. \& M. College, the State Colleges of Kansas, Iowa, Oregon, Washington and South Dakota, the Universities of Oregon, Purdue, Utah, Nebraska and Columbia, and at Colorado A. \& M. College.

At Oklahoma the assignment of faculty rank was reported by the librarian to be the best way of expressing the relation of the library staff to the rest of the faculty in terms easily understood by all. The librarian has the rank of dean; the associate librarian in charge of the Division of Technical Processes, the rank of professor and head of department; the assistant librarian in charge of the Division of Public Service, the rank of professor; the heads of the Reference, Loan, Documents, Catalog and Acquisitions Departments, the rank of associate professor; several other heads of departments, branch librarians and professional assistants, the rank of assistant professor; and the remaining group of professional assistants the rank of instructor.

1 Part I of this paper appeared in College and Research Libraries, 12:11-19, January 1951.
The titles of librarians are listed in the cata$\log$ with rank as follows: senior catalog librarian, with rank of assistant professor.

The assignment of faculty rank, reported the librarian:

... enabled us to get not only immediate increases in salary but also regularly scheduled increments at later dates. We already had the privilege of retirement benefits, and nearly all were accepted socially as members of the faculty, marched at commencement, etc.

Faculty salaries are for nine months of service, to which 20 per cent is added to those of the library staff for II months of service.

With respect to tenure, appointment to the rank of instructor shall be for one year at a time and shall carry no implications of continuous tenure. Except in cases of emergency, not more than three reappointments to this status shall be made. Initial appointment to the rank of assistant professor shall be for a period of three years, and reappointment for a second probationary period of three years may be made. Tenure shall be continuous during each three-year appointment period, and reappointment to this rank after six years of continuous service shall imply permanent tenure, except in cases of removal for cause. All initial appointments to the rank of associate professor shall be for a period of five years during which tenure shall be continuous, and reappointment to this rank implies permanent tenure status, except in cases of removal for cause. If an instructor, assistant professor 
or associate professor is not to be reappointed at the end of the academic year in which he is serving, he shall be given written notice by the head of the department not later than 90 days prior to the close of that academic year. All appointments to the rank of full professor shall be for life, except in cases of removal for cause.

Promotions from one faculty rank to another may be made upon consideration of demonstrated fitness, adequacy of training and experience in teaching or research, together with any special abilities which make the faculty member of value professionally to the college and the state. The qualifications for the various ranks shall be based on a recognition of merit primarily and on seniority as a secondary consideration. The criteria for recognition and evaluation shall become progressively more exacting from lower to higher ranks.

Annual leave with pay is provided for in the belief that it is mutually beneficial to both the staff member and the institution. All staff members may be extended such sick leave with pay as may be imperative upon application, provided that the college does not assume responsibility for payment of salaries beyond 30 days, except by express arrangement, to be governed by the circumstances in each separate case. The principle of granting sabbatical leave to provide staff members an opportunity for study and research in their chosen fields is regarded as mutually beneficial both to the institution and to the staff. Therefore, a staff member, having established tenure status, who has served six consecutive academic years at this institution may obtain leave at one-half pay for study, travel or improvement during the seventh academic year, or full pay during one semester of the seventh year.

The librarian of Kansas State College reports :
The library staff at Kansas State College has had faculty ranking for 30 years or more.... When our new appointees have had library school training we start them as instructors. It has been customary to have the associate librarian described as associate professor and the librarian as professor.... There never has been any question in my mind of the desirability of faculty rank for the library staff.

The Kansas State College librarian has described the work of the librarians to the administrative officers of the college as the interpretation of subject matter in much the same sense that the classroom instructor accepts this responsibility. In calling attention to "some decidedly important practical results which come from the possession of faculty ranking," he mentioned longer annual leaves, participation in the retirement plan upon a more advantageous basis, more adequate salaries, time and expenses for attendance at professional meetings, and last but not least, "the social programs of the campus are always built about the faculty, and nothing does more to build up respect and prestige for the library than the acceptance by the campus population of the library staff as members of the highest social group."

The director of the Iowa State College Library reported that when Dr. Charles $H$. Brown was appointed librarian in 1922 he was given the academic rank of professor and department head. He also became a member of the general faculty and of the Graduate College. In 1928 he was appointed to membership on the Administrative Board, a body comprised chiefly of deans and directors. All members of the professional staff of the library, even prior to 1922 , were considered as members of the faculty of the Division of Science. Although they did not have academic rank, they were eligible to attend faculty meetings of that division. In 1925 , at the time for- 
mal instruction of graduate students in bibliographic research was inaugurated, the assistant librarian was given the rank of associate professor. In 1930 two department heads were named to the rank of assistant professor inasmuch as they were in charge of the freshman courses in the use of books and the library. In 1938 a third department head, also active in instruction, was made an assistant professor. In I940, upon the recommendation of the dean of the Division of Science and the librarian, all other members of the professional staff of the library were given the academic rank of instructor. In 1947 two additional department heads were promoted in rank from instructor to assistant professor.

The Iowa State College library director also said :

I consider faculty rank desirable for members of the professional staff. ... The obtaining of faculty rank for professional librarians is a goal which should be realized eventually at all college and university libraries. ... Professional members of the staff should participate in various institutional activities; they should be persons of sufficient ability to warrant appointment to divisional and institutional committees.

The director of libraries of the Oregon State System of Higher Education reported: "The librarians in all the statesupported institutions of higher education in Oregon have had full academic status ever since our libraries were unified in 1932." The state system referred to includes the University of Oregon and its Medical and Dental Schools, Oregon State College, three colleges of education, and a recently established junior college in Portland. $\mathrm{He}$ stated further:

We have the generally accepted ranks of instructor, assistant professor, associate professor and professor, which is the highest academic rank in the system. The title of dean with us is considered an administrative title rather than an academic rank. The assignment of members of the various library staffs to the several ranks is determined by their experience, academic background and their contribution to the operation of the libraries. We have not had, and I should personally not want to have, any rigid regulations as to degrees or years of experience required to make persons eligible for the various ranks.

Regarding desirability the director remarked further :

I consider faculty rank for members of the library staff as highly essential. The fact that we do have such rank has, I am certain, definitely facilitated recruitment of new staff members during these past few difficult years. For one thing, all staff members with the rank of assistant professor (all our department heads and some others) are eligible for a year's sabbatical leave on half-time pay, or a shorter leave on full-time pay. This, too, is quite a selling point in adding to the staff. The fact that our librarians do have academic rank definitely contributes to the morale and "esprit de corps" of our librarians generally. We had occasion just this past summer to be very thankful for our academic status, as the State of Oregon is just putting into operation a new Civil Service Law. Had it not been for the fact that our librarians have academic rank, all of us would have come under the provisions of this new law to the considerable detriment, I am convinced, of recruiting and maintaining strong library staffs.

The University of Oregon's librarian reported :

Our professional staff does have academic rank here, and this policy has the full support of President Newburn who defended it vigorously last spring before the State Civil Service Commission. The librarian has rank of full professor. Department heads, who are supposed to have the master's degree, are assistant professors; and all others are instructors. ... I do consider faculty rank for librarians desirable. For a time it appeared to me that separate professional rank might be better, but I have since concluded that under such circumstances a librarian would be neither fish nor fowl and would suffer accordingly. 
Purdue University's director of libraries reported:

President Emeritus Edward C. Elliott believed and arranged that professional staff should be given faculty status and rank.... $\mathrm{He}$ felt that if they were to extend to the Purdue community the benefits proper and possible from a library, they would have to be of the same caliber or better than the community. The way to begin to arrange this was to give them the rank due to such educators.

A scheme of faculty status was presented to the Faculty Committee on Promotions. Personal data accompanied the recommendations for assistant professor on the basis of merit since this rank does not automatically go with the library position involved. The director stated further:

The educational work of the staff was stressed-for example, the intimacy with the curriculum and university purposes which the order librarian and head cataloger especially must attain; the face-to-face teaching work of the circulation and reference librarians.... For once such libraries were run quite generally by professors, who with relief turned the work (when growth became a tremendous problem) over to full-time librarians who were too often concerned with materials only. The need is, and always was, that the scholarship and pedagogical attitude of the professor be kept, to which would be added the practices and efficiency of library science.

Perhaps certain individuals do not fit such a scheme. We assigned the rank with this matter clearly understood. Such individuals can grow and develop as needed; time, or their own choice or administration can weed them out. The future promotions of the staff must follow the faculty pattern. Lectures, articles, writings must be achieved; courses and degrees taken; activity in professional organizations entered into and encouraged. This will mean time out from library posts and some departure from rigid functional, especially clerical, efficiency. The university administration, however, which expects its library to open students' eyes to the most certain path of postgraduate growth, to match faculty interest with bibliographical guidance, to use thousands of dollars so that collections will have independent vigor, to attract scholars to a campus, to possess resilience to meet curricular changes and research demands - this same university administration must expect to support, by fiscal and honorific reward, persons capable and adaptable for such achievement. The problem faced by the university administration today is one of sound and skilled development and use of an educational method-one quite the equal of classroom and laboratory-and to this end the library personnel is [a] factor and the key factor.

"Since 1917, with the appointment of an assistant librarian with the rank of instructor, qualified staff members of the library of the University of Utah have often been granted the rank of instructor or above," reported the librarian. In 1942 all library school graduates on the staff were granted the rank of instructor and the assistant librarian, that of assistant professor. In 1946-47 the rank of assistant professor was extended to certain other members of the staff. The librarian also stated that:

The dean of the faculty raised a question as to teaching titles for nonteachers but waived his objection when it was pointed out that the library has been classified as a department of instruction and investigation rather than as an administrative unit. It was likewise noted that members of the staff do give instruction in how to use the library and in courses for teacher-librarians.

In 1943 the board of regents adopted a set of employment regulations. .... An academic employee was carefully stipulated as one having the rank of assistant or above and employed as teacher, research worker or librarian.... With regard to vacation, librarians were granted one month and were included in that group of persons expected to be on duty between quarters. . . . Sick leave accumulates at the rate of one day for every 15 days of service, with up to 30 days a year without question. ... In 1946 the faculty, the deans' council and president approved a university-wide regulation that department heads consult their staff members before preparing their annual budget. In 
addition to watching the salary schedule, the department head is to consider professional attainment, length and nature of experience, efficiency, capability as a research worker and general service to the university.

The University of Utah librarian further reported :

The faculty council members have come to accept two ideas. One is that men or women of high caliber in library work, like teachers in engineering, need not have the doctorate in order to merit considerable recognition. The other is that we cannot afford people of this caliber for every job in the library. ${ }^{2}$

The Board of Regents of the University of Utah have approved a policy whereby library staff members, with the rank of instructor or above, may be granted one full quarter for study out of each eight quarters served at the university. Pay is to be granted as provided under the four-quarter plan. The leave and the program of study must have the approval of the librarian and the president of the university. ${ }^{3}$

The associate librarian of the State College of Washington Library reported:

In April I946 our president, with the approval of the Board of Regents, drew up a staff and faculty organization in which the professional library staff is recognized as a part of the college faculty.... The library staff is defined as the librarian, assistant librarian, heads of departments, reference librarian and the other professional personnel of the library.... College faculty shall include all members of the resident instructional staff, the noninstructional research staff, the library staff, the extension staff and the administrative staff. ... The librarian has the rank similar to full professor and is entitled to attend and vote at all meetings of deans and heads of departments. The other professional members of the library staff are privileged to attend and vote at all faculty meetings. The faculty rank is based upon the position held by the professional staff

2 These notes concerning the situation at the University of Utah are extracted from Kirkpatrick. Leonard $\mathbf{H}$. "Another Approach to Staff Status," College and Re search Libraries, 8:218-20, July I947.

3 "News from the Field," College and Research $L_{i}$ braries, $9: 176$, April I 948 . comparable to that of the president's committee recommendations. This application of faculty rank is highly desirable, and we find that our staff is much better acquainted with the problems of the campus and can anticipate needs of the faculty much more readily.

More recently, the librarian wrote,

The only change which has been made occurred recently when library staff were classified into L.I, L.2, L.3, L.4 groups, corresponding approximately to the ranks of instructor, assistant, associate and full professor, although the library staff do not actually carry academic rank by title.... My rank ... is somewhat that of a dean or director of a division rather than that of full professor, but I continue to hold my regular voting membership in the faculty.

At the University of Nebraska on Oct. 30, I948, the Board of Regents approved the following addition to its Rules and $B y$ Laws:

Academic ranks shall be given to individuals on the Library staff as they shall be recommended to the Board of Regents by the Library Committee acting through the $\mathrm{Di}$ rector of University Libraries.

This statement originated as a motion of the Library Committee. Subsequently, it was endorsed by the Chancellor's Administrative Council and forwarded to the Board of Regents with the recommendation of the dean of faculties.

On Feb. 10, 1949, the Library Committee recommended the rank of instructor for I 4 present members of the professional staff, the rank of assistant professor for II, including one member recently retired, and the rank of associate professor for the assistant director of libraries. Three of these recommendations to ranks higher than instructor were held in the office of the director of university libraries in order not to jeopardize the candidacies of these individuals for higher degrees at the University of Nebraska. The other 23 recommendations 
were formally approved by the Board of Regents on Feb. 26, 1949.

The director of university libraries has the rank of professor, is a member of the Chancellor's Administrative Council and an ex officio member of the University Senate.

The assistant director, General Administration, of Columbia University Libraries reported:

... the personnel are regarded as falling into two general groups: (I) nonacademic personnel which would include janitors, carpenters, elevator operators, typists and stenographers and others of this general category; and (2) academic personnel. The latter group are in turn divided into two types which are (a) teaching personnel and (b) nonteaching personnel, in which group the professional librarians come. The professional librarians do not receive any faculty title such as assistant professor or associate professor unless they are actually teaching courses at the university. Their standing as professional librarians is regarded as sufficient and I might add they are regarded with honor for being in that group.

Being in the academic group they have certain prerogatives on the same basis as members of the teaching group, including (I) listing in the Directory of Officers, together with the title of the position which they hold in the Libraries; (2) eligibility for membership in the Faculty Club; and (3) participation in the T.I.A.A. retirement plan. ... Section 85 of the Columbia University Statutes says: "Permanent members of the professional staff will rank with officers of instruction or officers of administration in respect to academic privileges."

The director of libraries at Colorado A. \& M. College reported: "All of the professional members of the library staff have faculty rating. . . I I highly approve of faculty status for professional librarians because they cannot correlate their work with that of the classroom teachers on any other basis." The general faculty of Colorado A. \& M. College specifically includes "members of the library staff of rank equivalent to that of instructor or higher."
The librarian of South Dakota State College reported that professional employees in the library "all have faculty status." The librarian is listed as a full professor. Section III on Membership, of a proposed revision of the State College Constitution, specifies that:

The Faculty Association of South Dakota State College shall consist of the following: ... (D.) Members of the Library Staff with rank equivalent to instructor or above. ... (F.) In interpreting the term "rank equivalent" with respect to any one individual, consideration shall be given to the matters of salary of that individual and of his professional training and experience. Any person whose work is not under the jurisdiction of the faculty administration shall not be considered a member of the faculty.

More recently, "The librarian is formally recognized as professor of library science. The assistant librarian also teaches some courses. It is expected that he will also receive a formal title.... All professional librarians are considered members of the faculty."

\section{Limited Faculty Status}

The principle of academic rank for professional librarians has also been accepted, though with reservations, at the following institutions: At the State University of Iowa the library professional staff is included in the academic category and its members are admitted to the faculty retirement plan. Professional library employees at the University of Michigan are appointed through the Faculty Personnel Committee and, in many respects, have been assimilated to the faculty group. Northwestern University reported that professional librarians have been classified as instructional and research employees. Several have been given academic rank and of those above professional grade two have been admitted to the university's retirement plan. The University of Chicago reported that all 
members of the library professional staff have academic status but are not ranked by academic titles nor included in the academic retirement system. The University of Arizona reported a partial application of faculty status to the principal librarians. Harvard University reported the inclusion of a substantial number of professional library employees among the "officers of administration" and a limited number among the "officers of instruction." Yale University reported the application of academic rank to heads of minor library departments and senior assistants in major departments, and to those individuals with larger responsibilities but accompanied by only a few of the desirable features implied in rank. Brown University reported the assignment of academic rank to several members of the library professional staff.

The director of libraries at the State University of Iowa reported:

At the present time the director and associate director and one member of the staff, who teaches courses in school librarianship, have professional rank and are members of the Library Education Department of the College of Arts and Sciences, but other members of the staff do not have this rank. However, the professional staff members are included in the academic category, are eligible for participation in the faculty retirement plans, and they are not under the jurisdiction of the director of nonacademic personnel. This situation will be changed when we get our new library building, but my own personal attitude is that faculty rank should be given only to those who teach, providing we can have a liberal interpretation of the term "teach."

The University of Michigan's director of the General Library reported:

All members of the staff of the General Library are classified. With the exception of the director, associate director and assistant director (and a small group of secretarial and stenographic personnel), the staff is covered by classifications $\mathrm{Li}$ I- $\mathrm{Li} 5$. Classification $\mathrm{Li}$ I includes clerical assistants and other subprofessional workers; groups $\mathrm{Li} 2,3$ and 4 are intermediate professional groups; and department heads are classified Li 5 .

All persons employed in the General $\mathrm{Li}$ brary, except those in group $\mathrm{Li} I$ and some stenographic personnel who belong to a $\mathrm{C}$ classification, are appointed through the Faculty Personnel Committee and in many respects have been assimilated to the faculty group. All members of the library staff, except the director and the associate director, however, participate in the University Employees' Retirement Plan, rather than the T.I.A.A. plan open to faculty members. The privilege of sabbatical leave is not enjoyed by librarians, and there remain other distinctions between them and the faculty group.

Northwestern University's librarian reported that the special character of the professional library staff has been recognized, and the professional librarians have been classified as "instructional and research employees." The following members of the library staff now have academic rank: the university librarian, the law librarian and the librarian of the Medical Library. When an assistant librarian is appointed he will be given academic rank. In addition, staff members in the university library above Professional Grade II have been admitted to the university's retirement plan, operated through the Teachers Insurance Annuity Association, on the same basis as university employees having faculty rank.

In order that the librarians in key positions may develop and maintain close contacts with the instructional and research program of the university, it is highly desirable that at least those librarians who are in charge of separate libraries-as well as the assistant librarian of the university library-have full faculty rank so that they may participate in faculty meetings, serve on faculty committees and become intimately familiar with the educational ends and means of the university.

The university librarian commented further:

To develop and maintain a competent li- 
brary staff, it is essential that the professional librarians receive salaries which are comparable, insofar as comparisons are possible, with those of the faculty; that they be eligible for participation in the Teachers Insurance and Annuity Plan so that they may be enabled to make librarianship a professional career; that, after having been with the university for a reasonable number of years, they may be assured of the relative permanence of their positions through tenure rules applicable as long as satisfactory service is rendered; that they be given an opportunity to engage in research through the granting of leave with pay when a special situation justifies it; that they receive some sort of social recognition, dignifying their profession, preferably by defining their status in terms of "equivalent academic rank." The attainment of these objectives would doubtless result in greatly improved staff morale, and would attract to the university competent professional librarians who might not otherwise be available for appointment.

On the other hand, it is quite obvious that the specific requirements and responsibilities of the professional librarians differ significantly from those of the faculty, so that a complete assimilation of the two groups cannot be achieved. Indeed, such an assimilation would hardly seem fair to either group inasmuch as the conditions that must govern qualifications, promotions, appointments and even tenure of the two groups are not identical. However, it should be possible to obtain the objectives set forth in the foregoing without necessarily making all the professional librarians actual members of the faculty.

The University of Chicago's chief of the Service Division reported:

All members of the professional and junior professional staff have academic status, but they are not ranked by such titles as instructor, assistant professor, etc.; nor is the library staff included in the academic retirement system except for those members of the staff who have joint teaching appointments, and except for the director and the associate director who are included in the retirement system by university statute, apart from their teaching duties. Titles of instructor, assistant professor, etc., are reserved for only those who are actually doing teaching.
At the University of Arizona the librarian has always had the rank of professor. Recently, the librarian reported:

Under the new faculty constitution adopted in $1947-48$, the assistant librarian and head of the Acquisitions Department, the heads of the Catalog, Reference and Circulation Departments, and the law librarian have been designated as "faculty." This has, in effect, given these positions no more than voting privileges in faculty matters. They are not uniformly recognized as faculty throughout the campus. They are listed in the university's catalog with administrative assistants. They do not share with the teaching faculty the retirement benefits which accrue to the latter. And for salary purposes, it has been impossible to tie these positions to any established salary floor for teaching positions because they have not been classified by rank.

The librarian of Harvard College Library, the central unit of the Harvard University Library, reported:

The librarian and two of the assistant librarians have the rank of members of the faculty of Harvard College. Two of the three... are full professors with the title of professor of bibliography. The third ... in addition to having the title of assistant librarian has attached to his name in the cata$\log$ "and member of the faculty." This makes the three ... not only officers of administration but technically officers of instruction.

A second group of officers of administration ... are not officers of instruction. These officers of administration are what is called "corporation appointments." Their names appear in the catalog in the same alphabet with officers of instruction, and they have all the rights and privileges of officers of instruction except going to faculty meetings. Their appointments are made the same way. There are about 17 people who fall into this category and who make up the senior group of men on the staff. The other nine-tenths of the staff do not have corporation appointments, and are simply appointed by the librarian with no restriction so long as he keeps within the budget and follows the general rules for employment at Harvard.

Yale University's associate librarian re- 
ported: "Academic rank is somewhat generally assigned as follows: heads of minor departments and senior assistants in major departments have the rank of instructor; heads of major departments have the rank of assistant professor; the librarian of one large school library and the associate librarians have the rank of associate professor." The librarian of another major school library has the rank of professor, by virtue of his teaching assignment, and the librarian has the rank of professor. The associate librarian appended a list of 36 positions, with corresponding faculty ranks, out of a staff totalling 167 . In addition, a number of curators give some time to the library but have faculty rank in connection with their teaching. The associate librarian stated :

Faculty rank for the library staff, as practiced at Yale, presents only a few desirable features. There is, of course, the social and prestige value. An indication of rank in the faculty directory is probably of aid to the staff member in his dealings with the faculty and in his nonuniversity community relationships. Rank gives a certain amount of preference in such matters as tickets to commencements, convocations, athletic games and parking. All persons with faculty ranks are eligible for membership in the Faculty Club and the rank of assistant professor allows participation in the university's annuity program.

In answer to your question concerning the desirability of this application of faculty rank, I think we should say that, while helpful insofar as it goes, it falls far short of extending to the library staff the privileges and opportunities given to faculty members with similar rank. Only the librarian is entitled to attend the meetings of the various faculties. The statutes governing sabbatical leaves of absence refer only to professors, associate professors and assistant professors, without regard to the department, so it may be inferred that the provisions would apply to library staff members with the above ranks. We have, however, no experience to warrant such an interpretation. Long vacations do not apply to staff members with faculty rank. Perhaps the feature that is most unhappily absent is a clear recognition that librarians in responsible positions benefit, as do their institutions, from time comparable to that granted to faculty members for consecutive study or investigation that is so necessary for their development. A faculty member has this opportunity and he is enabled to keep up with his field; a librarian cannot do so on top of a full week's work nor in the one month out of 12 that he is free from library duties.

The acting librarian at Brown University reported:

At the present time the librarian is John Hay Professor of Bibliography and teaches a graduate course; the assistant librarian, the librarian of Pembroke College Library and the supervisor of readers' service have the rank of assistant professor; the head cataloger and the assistant in charge of the Social Studies Reading Room have the rank of instructor. On our recommendation to the university administration, faculty rank has been assigned on the basis of advanced academic training (comparable to that of the instructional staff) with some consideration of experience in the library field and present responsibility.

\section{Efforts to Win Faculty Status}

The University of Minnesota reported the application of academic rank to a limited number of librarians and a lively interest in its extension, and reported also that some of the benefits commonly sought are already available through the present administration of the University Civil Service. The librarians of the following institutions expressed an interest in the assignment of academic rank to professional members of the library staff and a hope that it may be extended in their institutions beyond its present limited application. At the University of Pennsylvania full faculty rank has been given only two librarians, the director and the law librarian. At Ohio State University faculty status has been given to the director and the associate $\mathrm{di}$ rector. At the University of Oklahoma 
the librarian and the assistant librarian have faculty rank. The University of Missouri, the University of Kansas and Pennsylvania State College likewise reported that their library staffs are without academic rank, but their librarians expressed an interest in securing such rank.

The University of Minnesota's assistant university librarian reported:

Concerning academic status for the professional staff, we are just now in the midst of considering that matter. . . At present the entire staff, with the exception of the university librarian and assistant university librarian are under the university's Civil Service. However, our recently formed Staff Association is very much interested in the matter of status and plans to discuss the possibility of requesting academic status for the professional staff. ... The university librarian holds the rank of professor, the assistant university librarian and the chief reference librarian, the rank of associate professor, and the chief order librarian, the chief catalog librarian and the librarian of the MedicalBiological Library, the rank of assistant professor.

Since the library staff has actually benefited considerably from its inclusion in the university's Civil Service, it will be cautious in requesting academic status, unless it is assured of retaining the benefits it now has. However, to counteract the salary benefit it enjoys, the staff is now held to a 40 -hour week and 12-to-15-working days vacation (except for department heads) which it would like to see eliminated if a more liberal program of working conditions could be obtained by appealing for academic status.

\section{And more recently, the Staff Association:}

... did present its case in 1947 (before a Senate Committee set up to redefine criteria for academic status). The committee recommended continuing the present criteria, at least 50 per cent time spent in teaching or research, so the status of the library staff remains unchanged.

The University of Pennsylvania's director of libraries reported:
There are only two librarians here at the University of Pennsylvania who enjoy full faculty rank, namely the director of libraries, who is also professor of history, and the law librarian, who is also associate professor of law. The dental librarian, who is also lecturer in dental bibliography, enjoys faculty privileges except that she is not included in the faculty retirement plan.

Faculty rank for myself was arranged with some care when I was first appointed, in the belief (which the event was to have justified) that the library interest would be fostered by strengthening my hand and increasing my influence. In my opinion there are certain other librarians in the main library who ought to have faculty rank, namely, the assistant to the director; the assistant librarian, Service Division; the assistant librarian, Preparation Division; and probably also the curator of the Rare Book Collection. Also it seems to me that faculty rank should be extended to several of the departmental librarians besides the law and dental librarians. Already one forward step has been taken in that by special executive action the privileges of the faculty retirement plan (T.I.A.A.) have been granted to the small group above named in the main library; but their privileged position has not been institutionalized, and a recent attempt to obtain faculty retirement privileges for all the professional librarians on campus has failed.

Ohio State University's librarian reported:

The matter has been up for discussion with our administration several times, but I regret to say, no action has been taken leading in this most desirable direction. The difficulty appears to be with us ... that we have a very considerable number of people attached to various departments, bureaus, etc., who do not do actual teaching of courses and whose status, like that of the library staff, is neither fish nor fowl. To add the professional members of the library staff to the faculty involves certain adjustments to the list of people on various kinds of appointments. It also opens up the question of university retirement on faculty basis, a matter of considerable interest to us, but one involving financial problems which the administration has been unwilling to assume, largely because opening the door to the library staff would 
immediately be followed by similar demands from a great many other people, necessitating saying yes to some people and no to others. From an academic standpoint of degrees attained, many of these people are as well qualified as members of our instructional staff, but the problem is very complex. . . . Faculty status has been given to the director and the associate director.

The University of Oklahoma's librarian reported:

The members of our staff at present do not have faculty rank except the librarian who has a rank as professor, and the assistant librarian who has the rank of associate professor. We have considered the matter and I think it is likely that we may send an outlined recommendation to the university president and the Board of Regents asking for faculty rank for all of the members of the staff. . . . I should think that heads of the various departments such as the Catalog Department, Order Department and the Reference Department, could probably have the rank of at least associate professor; others would have the rank of assistant professor or instructor according to their training and experience.

From the office of the librarian, the University of Missouri, came the following report :

The library staff ... does not have faculty status. The members are listed in the faculty directory and are privileged to become members of the faculty clubs. The heads of departments are eligible for annuity after three years' service. Working hours are based on the university administrative staff schedule except that they are 42 rather than 44 hours per week. Appointments are made on a 12month basis with one month paid vacation and two weeks sick leave.

The director of the university library, the University of Kansas, reported:

No faculty rank is accorded the library staff. The director is a member of the University Senate. ... At this library it has seemed more important to try to raise the salary level than argue for rank. I'd like to see faculty rating accorded the trained staff but we rest for the present on the fact that the women librarians are admitted to the Faculty Women's Club.

The librarian at Pennsylvania State College reported that it "has not assigned faculty rank to its library staff." The librarian added, "I presume you have read Mr. Downs' very excellent article . . . relating to faculty rank for library staff at the University of Illinois," theteby indicating a sympathetic interest.

\section{Faculty Privileges But Not Status}

In her study Io years ago, Maloy remarked that:

Some groups of librarians have felt that more immediate advantages could be gained in their particular institutions by stressing and developing their unique status as librarians, raising their own standards, developing their own potentialities, and bringing to the attention of the college authorities the educational and cultural requirements of the library profession. ${ }^{4}$

This appears to reflect the attitude of a minority group of administrators among the 35 libraries studied.

At the University of Colorado, professional members of the library staff are classified in the professional and administrative service, distinguished on one hand from the faculty and on the other from the clerical, maintenance and auxiliary service. At Wayne University the professional members of the library staff do not, technically speaking, have faculty rank, but they do have most of the privileges associated with such rank. At the University of California; Berkeley, the librarian believes that a better approach to improving status for librarians is to determine desirable benefits and to attempt to secure them severally, rather than to seek to acquire them by blanketing librarians into faculty ranks.

4 Maloy, Miriam C. "Faculty Status of College Librarians." A.L.A. Bulletin, 33:302, April 1939. 
At Indiana University, too, the librarians are classified among the nonacademic personnel, but with a number of privileges which are equal to those of the faculty. The librarian believes that rank should be applied only to employees engaged in teaching, which is, presumably, classroom teaching. At Cornell University a few members of the library staff have faculty rank, but the director of the university library is doubtful of the desirability of trying to secure faculty rank for all because many do not have the qualifications for appointment to the instructional staff. At the University of Texas the librarians are classified among the nonacademic personnel, though the librarian believes that rank should be obtained when the employee is engaged in teaching. At Duke University only the librarian and those members of the professional staff who also teach have faculty rank.

At the University of Colorado three major divisions of university employees have been established. The "faculty" is limited to individuals who are devoting a majority of their time to formal classroom teaching or organized research. The "professional and administrative service" includes those classes of positions which involve either significant administrative duties or significant duties in occupations which have obtained recognition as professions. The third group is the "clerical, maintenance and auxiliary service." All professional members of the library staff are now in the "professional and administrative service."

The librarian of Wayne University reported :

Technically, the professional members of the library staff . . . do not have "faculty rank." . . We occasionally make use of such general university classifications as research associate, senior university assistant, etc. It would be perfectly possible for us to appoint a qualified staff member as an associate professor or at any other professorial rank.

We have never made any effort to secure professorial rank for members of the library staff simply because we cannot justify in our own minds such a classification, and because we see no real advantage which would accrue to members of the staff. In all such important matters as tenure, retirement benefits, etc., no distinction is made between the library staff and the teaching staff. Furthermore the qualifications required for appointment to and promotion on the library staff are significantly different from those required on the teaching staff. The income of members of the library staff is higher than that of members of the teaching staff whose formal qualifications are about the same.... The less material aspects of status, at Wayne, are very close to those which each member of the staff earns and deserves. Those who are professionally and intellectually the equals of the teaching staff are so accepted and respected.

The librarian of the University of California, Berkeley, reported "that professional employees of this library do not have faculty rank." He commented further :

I do not consider that the device of seeking faculty rank is the only, nor in many situations the best, means of securing improvements in salaries, retirement benefits, etc. Librarians should stand on their own feet as a group which makes a contribution deserving recognition. I feel that a better approach to the question of improving status for librarians is to determine desirable benefits and to attempt to secure them severally, rather than to seek to acquire them by blanketing librarians into faculty ranks. ${ }^{5}$

There are, sometimes, situations in which the inclusion of librarians in the faculty categories is the simplest way to achieve this end, but often this course meets strong resistance. Faculty may hold that librarians do not qualify as faculty. An objective examination of the two groups supports this view. Librarians' work is not comparable to teach-

5 See, for example, Bryant, Douglas W., and Kaiser, Boynton S., "A University Library Position Classification and Compensation Plan." The Library Quarterly, I 7 : I-I 7, January 1947. 
ers' work. I say this without any intention to discredit either. The character of the preparation for the two lines of activity and the criteria for advancement are quite different. I think we are abliged to say, if we look at the rank and file of professional ememployees in university libraries, that their preparation is neither as substantial nor as demanding as that required of professors.

The director of libraries at Indiana University reported:

Our professional librarians are classed as nonacademic personnel. We have, however, a number of privileges which are equal to those of faculty. As an example, the university is now engaged in amending its provisions so that professional librarians may be included in the T.I.A.A. plan rather than in the state employees pension plan. We are unconvinced that librarians who do not engage in teaching should have teaching title or rank.

The director of the Cornell University Library reported that "the director of the university library and the assistant directors are members of the university faculty by statute." There is no specific rank and the question has not been raised, but the director's position is considered to carry a professorship.

The librarian of the Law Library is a professor, as is also the librarian of the Agriculture Library; the librarian of the College of Home Economics is an assistant professor; and the librarian of the Veterinary College will probably be given status.... No other members of the staffs of any of the libraries have faculty rank. ... It should perhaps be noted that the law librarian has a law degree, not a library school degree and has ... been a member of the faculty for years. The agriculture librarian has a Ph.D. in economics and was a full professor in the College of Agriculture before his appointment as librarian. He has retained his professorship, although he no longer does any classroom teaching.

The Cornell University librarian further reported :

I am doubtful of the desirability of trying to secure faculty rank for all of the professional members of the library staff. In many cases professional librarians do not have the qualifications which would be required for appointment to the instructional staff and since they lack these qualifications, an assignment of faculty rank is in my judgment an artificial device which means very little to anyone. If faculty rank is not merited and does not carry full significance, I consider it undesirable. In my opinion a good case can be made for paying librarians decent salaries as librarians and not as quasi- or pseudofaculty members. There are, of course, certain members of the library staff in most large institutions who do have the qualifications for faculty appointment and who perform functions of an instructional nature.

I think it is desirable to have more people on the library staff who do have the qualifications necessary for faculty appointment and I hope that in the years to come we may see many appointments of this kind to appropriate library positions. When persons with such qualifications are appointed to library staffs I should certainly consider it desirable that they be given faculty rank.

At the University of Texas the librarians are classified among the nonacademic personnel. The librarian reported:

It would be highly desirable from a practical point of view if faculty ranks could be given; or if, as the University of Illinois has done, assign a rank to a position on the theory that that rank would obtain if and when the employee was engaged in teaching. The library staff tends to be the forgotten group among the university's professionally trained employees. All too frequently they tend to be classed with the clerical employees.

Here is expressed a belief that academic rank belongs only to those who engage in classroom teaching, but obviously the professionally trained educational staff of a university includes many individuals who do not conduct formally organized classes. Here, too, the writer has misunderstood the application of rank at the University of Illinois where academic rank has been assigned to all professionally trained librar- 
ians but academic title only to those who teach in class.

The librarian of Duke University reported :

Only the librarian and those members of the professional staff who also teach have faculty rank. Professional staff members may participate in the university's annuity (retirement) program after two years on the staff. They are not eligible for sabbatical leave.

\section{Summary and Conclusions}

In summary, the educational function of the library and the academic responsibilities of its professional staff appear to be clearly recognized in most of the 35 institutions studied. In 14 institutions, including the University of Nebraska, the identification of the library professional staff with the teaching and research staff, rather than with the administrative and clerical staff, has been firmly established, and in most instances the assignment of rank with its attendant privileges has been accepted as the most appropriate means of expressing this close relationship. In eight institutions, librarians have been accepted into the ranks of the faculty with varying reservations and limitations. In seven of the remaining 14, the librarians expressed an interest in securing assignment of academic rank to professional members of the library staff and the hope that an extension of such an assignment might be secured beyond its present limited application. In the remaining seven, the assignment of academic rank is not regarded as the most convenient or suitable means of securing the recognition to which the majority of professionally trained librarians in the academic community would appear to be entitled at the present time.

\section{Joint Committee on Library Education to Study Adequate Training for Personnel in Specialized Libraries}

The Joint Committee on Library Education of the Council of National Library Associations met in Cleveland on July I6, I950.

One of the most important actions taken was to set up a subcommittee under the chairmanship of Edward N. Waters to make a survey determining the most desirable educational preparation for work in special libraries. The needs of libraries serving the various professions such as law, medicine, music, business and banking, as well as other technical libraries, will be studied to serve as a guide in developing programs of training in library schools.

The members of the committee are representative of library schools and general libraries as well as the subject specialties. They are: Leon Carnovsky, Graduate Library School, University of Chicago; Eleanor Cavanaugh, Standard and Poors, New York City; Robert B. Downs, University of Illinois; George Freedley, Theatre Collection, New York Public Library; Walter Hausdorfer, Temple University Libraries; Sanford V. Larkey, Welch Medical Library, Johns Hopkins University; Julius Marke, Law Library, New York University; Mary Louise Marshall, Tulane University Medical School Library; Louis Shores, Florida State University Library School; Maurice F. Tauber, School of Library Service, Columbia University; Melvin Voigt, Carnegie Institute of Technology; Edward N. Waters, Music Division, Library of Congress, chairman.

The cooperation of all the national library associations concerned with this problem will be sought and the aid of many individuals will be enlisted who may not be members of the joint committee. A preliminary meeting and discussions have taken place, and it is conservatively estimated that it will require two years to complete the project. 